＜原 著 >

\title{
日本人大酒家の肝病変一特に米国人 大酒家肝病変との比較病理
}

$\begin{array}{lll}\text { 柄沢 } & \text { 勉 } & \text { 志方 俊夫* } \\ \text { 金田 櫛田 智子 } \\ \text { 春雄 } & \text { 大久保 仁** }\end{array}$

要 旨: 日本人大酒家130例の肝病変を, 米国人大酒家238例との比較において病理組織学的に検 索した. 日本では女性症例が非常に少なかった。日本人大酒家にる米国にみられる様な典型的な アルニール性肝障害がみられたが, 頻度はかなり低く，かつ比較的軽度であった．逆に日本人症 例では, 慢性肝炎の像を呈する症例が多く, 肝硬变像も米国例と全く異り, multilobular の結節 を特徵とした.この差は;, 両国大酒家のアルコール摄取量の差, さらに肝炎ウイルス等の関与等 が, 重要な決定因子と思われた。

索引用語： 日本人大酒家 米国人大酒家 アルコール性肝障害 慢性肝炎

\section{はじめに}

種々の疾患の罯患傾向が，国により異なる事は稀でな いここれは異なった種属の素因差による事むあるらが， 地域性, 環境衛生, 生活習慣, 食䬦等の差異む重要な因 子である．䀒疾患についてもこの事が云える．欧米諸国 に和るコルコール性 (エタノール) 肝障害に対して， 本邦を含めたアジ諸国におけるウイルス性肝疾患は， その良い例である. 元来, 日本人のアルコール性肝障害 は，かなり稀なるのとされ，特にアルュール性肝硬変の 存在に対しては，否定的な見解もあった．しかし近来， 日本文化の欧米化にしたがい, 酒精领料の変化, 领酒量 の増大と共に，欧米にみられる様な典型的なアルュール 性肝障害の增加が注目されているる 本人大酒家の肝病変を明らかにすべく，米国人大酒家の 肝病変との比較に拈いて, 病理学的検索を行った.

\section{材料之方法}

対象は日本人大酒家130例，米国人大酒家238例であ る. 日本人症例は, 日本大学板橋病院 (42例), 同大学騊 河台病院 (78例) 括よび東京大学附属病院 (10例) の䤠 例で，臨床診断は種々のアルコール性肝障害（アルコー ル性肝炎，アルコール性肝硬变，フルコール性脂肪肝

*日本大学医学部第 1 病理

** 日本大学医学部第 3 内科 <受付日53年 8 月 7 日 $>$
等)，またはその䇬いである，大部分の症例で，血中 Hepatitis B surface (HBs) 抗原の検索が行われて括り, 陽性症例は含まれていないまた血中 HBs 抗原の不明 な症例では，過去に輸血の 既往が判明していれば対象 より除外した.ささらに形態学的に, ground glass appearance をっった肝細胞を認めた症例も除外した． 約半数 の提例で志方等のオルセイン染色を行い, 全て陰性の症 例である. 東大の症例 (10例) は, 病理検查体頼用紙の 臨床データに体ったが, 日本大学の120症例では, 個々 の患者の病歴の記録を調べて情報を得た．米国の症例 は, Cincinnati 大学, Cincinnati General Hospital の 1966年から1975年迄の約10年間にわたる症例で，臨林診 断は，同様にアルコール性肝炎，またはアルコール性 肝硬変であった. noncirrhotic acute alcoholic hepatitis （後述 1 群A）の62例については，隍床データは，個々の 患者の病歷の記録の review によって得られたが，その

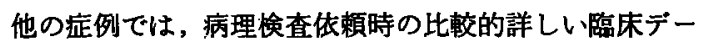
夕の報告により情報を得た．HBs 抗原陽性例は含まれ ていないが，検索のなされていない症例も多かった。 肝細胞の ground glass appearance を有する症例は含ま れていないが，輸血の既往による除外はなされていな い. 日本人症例の 2 例（肝外閉塞性黄疸の臨床詅断で, 発熱, 白血球增多症, 黄疸等の急性炎症症状の軽減後， 開腹されて得られた wedge biopsy の標本)を除き，両 
$2: 116$

肝

tro

国の症例は全て針生検肝で，全て10\%爰衝ホルマリンに

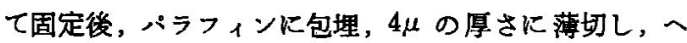
マトキシリンエオジン染色, アザンマロリー又はマッソ ンのトリクローム染色を行った. 膠原線維の検索には, 全例にて偏向レンズにての鏡検す行った。尚，米国症例 の検索は，1972年 7 月より，1975年 6 月までの間，柄沢 がシンシナッチ大学の病理レジデントとして留学中に, senior staff の協力を得て検索した．日本症例は，㷌国 後共同著者と共に検索した。

\section{結果}

米国人症例は黒人 129 例，白人 90 例で人種不明の 19 名 中に日系人の名前は無かった，日本人症例中には勿論， 異った人種の症例は無い、男性対女性の比をみると，日 本人症例では127対 3，米国人症例では142対89（7名は 不明) であった. 米国例のアルコール摄取量は，一部の 症例を除き不明であるが，1群Aの noncirrhotic acute alcoholic hepatitis の症例では, 大体, 少くともウイス キーを 1 日0.47l を10年以上連日饮んでいた。 その他の 症例では, 全て heavy drinker for many years として記 载されてあった．臨床診断の一つとしてアルコール性肝 炎を含んでいても， moderate drinker の3 症例は除い た.これら heavy drinker 特よび moderate drinker の 定義は不明であるが, heavy drinker については 1 群 A の症例と同様な摄取量と思われる.日本の症例では，そ の殆どが 1 日 5 合以上の日本酒を 10 数年以上にわたり飲 み続けており，1日1升酒の症例多数あった．しかし 少数ながら（特に女性で），1 日 3 合で約 10 年間程度の飲 酒歴の症例む含まれていた. 勿論大酒家より得られた飲

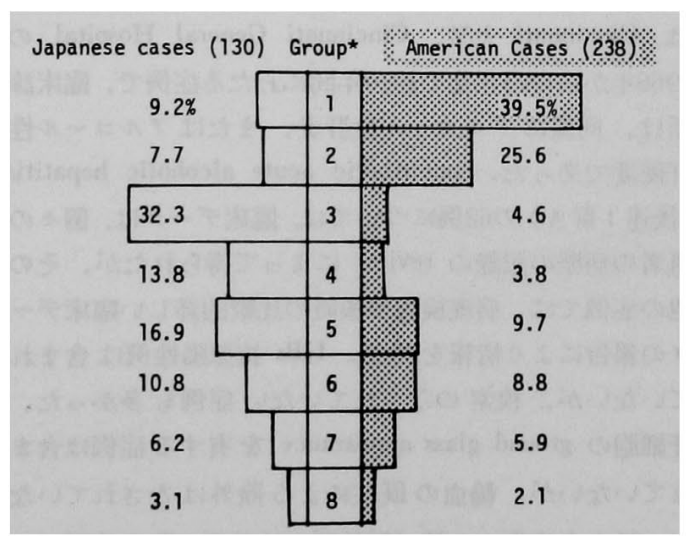

Fig. 1 Frequency of individual pathological diagnosis in 130 Japanese alcoholics and 238 American alcoholics (*See Table 1 or read text)

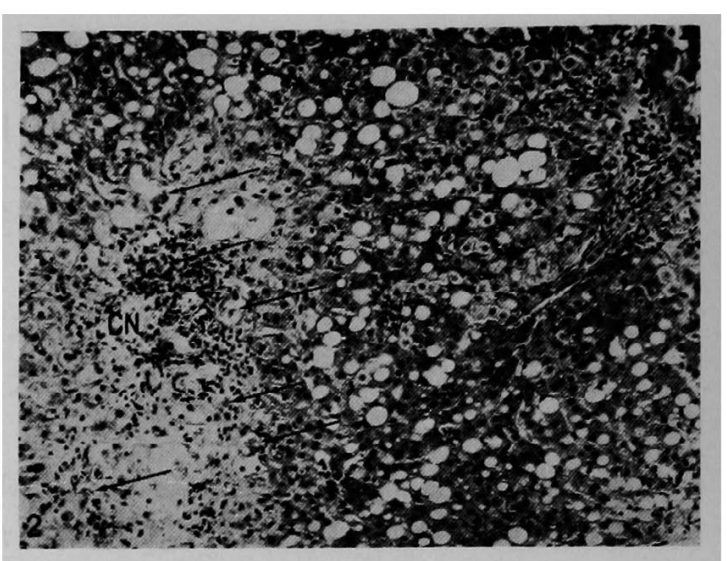

Fig. 2 There is centrilobular necrosis (CN) with marked neutrophilic infiltration. Multiple ballooning liver cells and several alcoholic hyalins (arrow) are seen in the same area. Portal area (P) is the site of mild neutrophilic and lymphoid cell infiltration. Mild fatty metamorphosis of liver cells is an additional finding. H.E. $\times 600$

酒歴の信恣性については礙問の多いところである.両国 大酒家の肝病理形態像は, Table 1 の如く分類された. 更にこの結果を各々の国における発生頻度(\%)としてみ たのが Fig. 1である. 即ち，1群は急性アルコール性 肝炎 (Fig. 2) を有する应例群である.これはフルコー 儿硝子体 (Fig. 3), 肝細胞変性, 壊死, 好中球浸潤を 必須所見とし, 他に肝細胞の巨系粒体 (Fig. 4) や, 肝

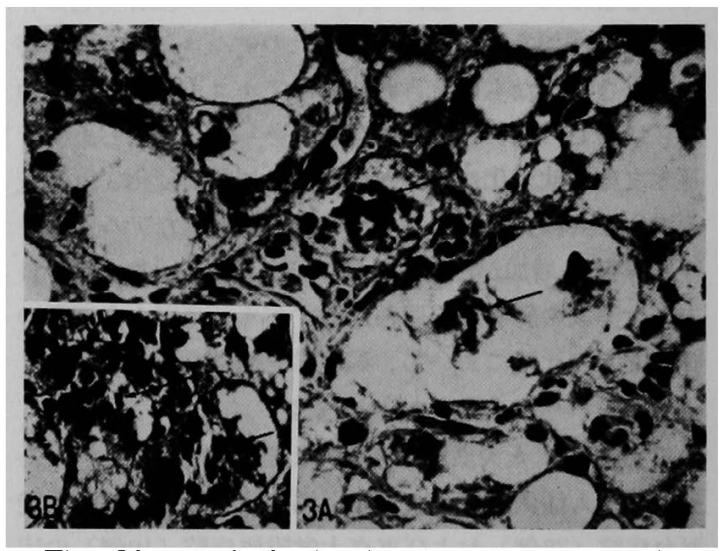

Fig. 3A Alcoholic hyalins (arrow) are seen in swollen liver cells surrounded by several neutrophiles. H.E. $\times 600$

Fig. 3B Alcoholic hyalins (arrow) are seen in swollen liver cells surrounded by multiple neutrophiles (satellitosis, long arrow) from American case. H.E. $\times 600$ 


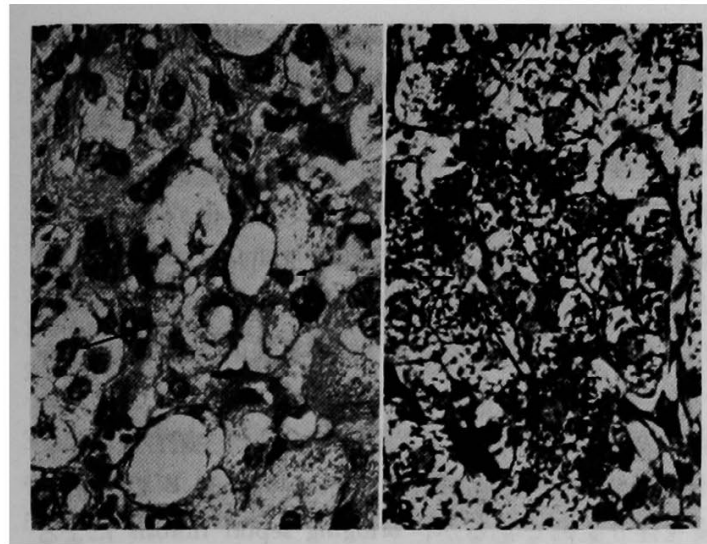

Fig. 4A Spherical giant mitochondria(short arrow) are present in liver cells. Liver cells are generally swollen with cytoplasmic granularity representing mitochondria. Alcoholic hyalin (long arrow) is also seen. H.E. $\times 600$

Fig. 4B Numerous spiculate giant mitochondria (arrow) are found in multiple swollen liver cells. Azan-Mallory. $\times 600$

細胞の脂肪化，小葉中心部線維化，肝細胞索に沿った線 状の線維化，中心静脈壁 の線維珄肥厚を特接としてい た．肝細胞変性としては，特に ballooning が著明であ り，肝細胞壊死の形は好中球漫潤を伴った lytic necrosis が特徵的であった.アルコール硝子体やこれらの肝細胞 変性, 壊死は, 肝硬変を伴わない時は, 小葉中心部にみ られ,これらのアルュール硝子体や肝細胞変性・壊死が 多数みられるときには, Rappaport の liver acinus の末 梢部に一致して小葉中間および周辺部にまでみられた。 肝硬変を伴う時は，アルコール硝子体は，肝硬変結節 の周辺部に多くみられた.アルコール硝子体をむち, ballooning 変性を扢こした肝細胞が，周辺に好中球浸潤 を伴い, 肝硬変結節間の線維性結合組織の中に, 埋もれ ていたり, 更に, 肝細胞の輪郭が殆んど消失し, アルコ 一ル硝子体のみが，同様に好中球浸罣を伴い，線維性絬 合組織の中に埋むれている事すあった．両国の症例を比 ベると明らかにこれらアルコール硝子体の頻度, 肝細 胞変性壊死，好中球漫潤等に差があり，米国例でより著 明であった．特に，周辺に好中球浸潤 (Satellitosis)を 伴ったフルュール硝子体 (Fig. 3B) は日本人例では, 非常に稀であった.アザンマロリー染色，マッソンの トリクローム染色, ルワソール,ファーストブル染色, フロキシメチレンブル染色等によるアルニール硝子体の 染色性には，両国間に差異はなかった。肝綝胞の巨糸粒

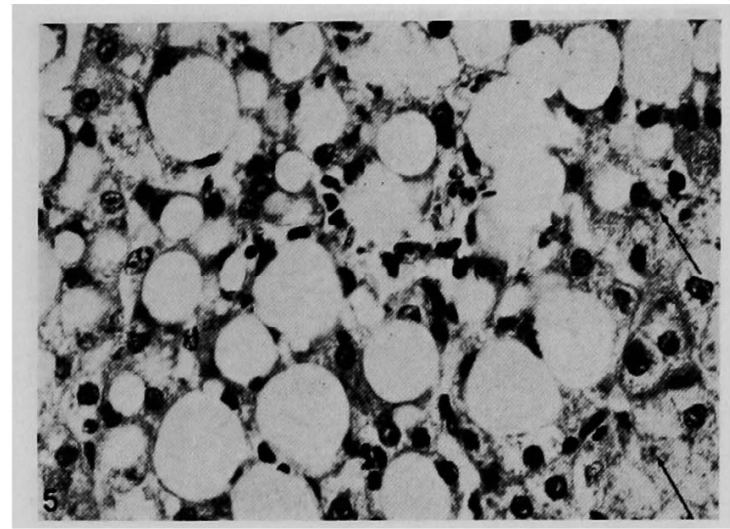

Fig. 5 Probable acute alcoholic hepatitis (Group 2). Marked fatty metamorphosis, neutrophilic infiltration, lytic necrosis of individual liver cell, spherical giant mitochondria (arrow), some swollen liver cells with granular cytoplasm are microscopic features. Alcoholic hyalins, however, are lacking. H.E. $\times 600$

体 (Fig. 4A，B) は, 細胞質内の好酸性の球状又は楝状 の構造物としてみられ，特に前者の球状のものが，特敂 的であり, 後者の棘状のもの多数が, 1 個の肝細胞内に あると,フルコール硝子体とかなり類似していたが， マトキシリンエオシン染色です区別がつき，更にアザン マロリー染色で，アルコール硝子体は青紫色に染まり， 巨米粒体は赤く染まるので鑑別が可能であった．肝細胞 の好酸性変性は，一般に稀であったが，好酸性小体の出 現は,かなり稀であった. 胆汁らっ滞像は, 総ビリルビ ン值の上昇に比し，明らかにより軽度であった。門脈域 の浮腫, 好中球漫閏, リンパ球の浸潤もみられた。門脈 域の線維化は，小葉中心部線維化の高度のもので，かな り強い症例があった. 2 群, probable acute alcoholic hepatitis (Fig. 5) は, アルコール硝子体を欠く以外は, 1 群と同様な組織像であるが，一般にその程度は，1 群より軽度であった． 3 群は Acapulco 分類 ${ }^{3)}$ に従った chronic persistent hepatitis (Fig. 6) であり，4 群は, 同分類に従った， chronic active hepatitis (Fig. 7) で ある. 5 群は nonspecific reactive hepatitis, 又は minimal hepatitis で, 主として門脈城, 稀に小葉内に軽度 のリンパ球漫潤と, 軽度の肝細胞壊死 (単細胞壊死中巣 状壊死）を稀に伴うすのである. lipogranuloma の比較 的古くなったものもみられた，同時に肝細胞壊死が殆ん どなく, 主として門脈域, 稀に小葉内に軽度の炎症性細 


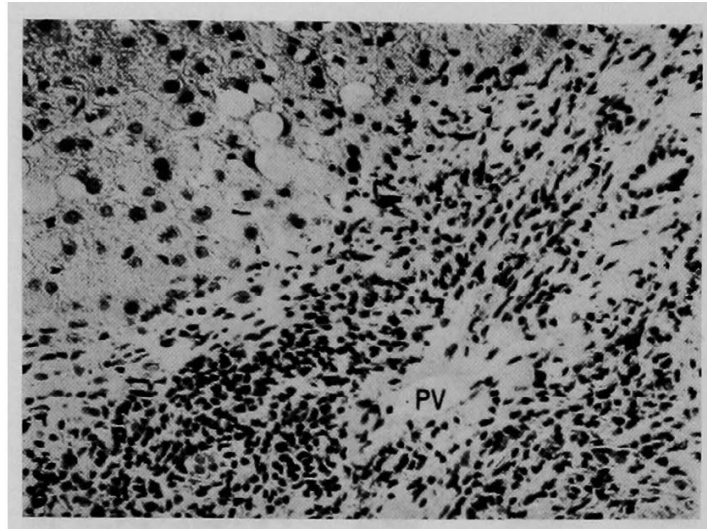

Fig. 6 Chronic persistent hepatitis (Group 3). Moderate chronic inflammatory-cell infiltration is present in a portal area. The limiting plate is intact with no piecemeal necrosis. Wall of portal vein (PV) is slightly sclerosed. H.E. $\times 300$

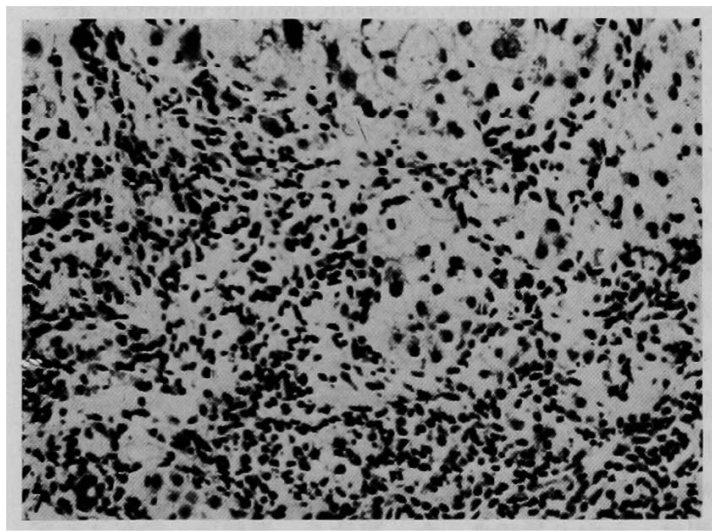

Fig. 7 Chronic active hepatitis (Group 4) Severe chronic inflammatory-cell infiltration is extending into the periphery of a liver lobule. The limiting plate is eroded with piecemeal necrosis. Bile ductular proliferation is present. Liver cells are generally ballooned. H.E. $\times 300$

胞浸潤（主として単核細胞，稀に好中球等）を認めた症 例 (nonspecific reaction) むこの群に含めた。この群に は, 種々の程度の肝細胞の脂肪化を伴う事む多く, 時に 6 群の脂肪肝の群に入れるべきかと迷った症例すあった が，炎症細胞の浸潤があるすのは，5群に入れた。これ 5の3，4，5群にす症例によっては, 小葉中心部線維 化，中心静脈不明化，肝細胞索に沿った線状の線維化， giant mitochondria, 肝静脈と思われる小血管の壁の線維 化がみられた．以上の5群については，さらに肝硬変の 有無により，A，Bの subgroup にわけた。 subgroup A
は，肝硬変を伴わぬ症例群であるが，中等度までの小葉 改築傾向をむった線維化を認める症例む含んだ. 特に， この線維化は 1 群と 2 群に打いて一定の㑯向がみられ た. 軽度のものでは, 小葉中心部に線維化がみられ,こ れが高度になるにつれて, 門脈域の線維化がみられた。 線維化が高度になると，小葉中心部間㧍よび小葉中心部 と門脈城を結ぶような線維性結合組織の隔壁が時折みら れたが, 閒脈域間を早期より結ぶ線維化は比較的稀であ った. 勿論, 例外むあり, 門脈域に, 小葉中心部より, より優勢な線維化をみ，門脈域間の線維性結合組織によ る連結るみられた症例るあった。 subgroup B は, 肝硬 変を伴 5症例であるが, bridging septal fibrosis による 小葉改策像も，場所により完全でなく，肥大性結節形成 も不完全な early cirrhosis の症例を含んた。. 稀に subgroup A にいれるべきか，Bにいれるべきか迷った症例 もあった． 6 群は脂肪肝の症例で，炎症性細胞浸潤の 無い症例に限定した。ここです特に小葉中心部に perihepatocellular の linear fibrosis をみた。７群は，上記 以外の組織学的異常所見を伴うるのであり，急性ウイル ス性肝炎や肝細胞障害性の薬昘性肝障害を思わせる症例 (日本人 7 症例，米国人 3 症例)，胆汁5っ滞症（米国 人 4 症例), cholangiolitic hepatitis (米国人 3 症例), 原 発性肝癌（米国人 2 症例)，著明な゙モシデローシス（日 本人 1 症例, 米国人 1 症例)，肉芽睡形成(米国人 1 症例) 等をみた症例である．8群は，組織学的に殆んど異常を みなかった症例群である. Table 1 で，斜線の左（分子） が日本人症例数, 右(分母)が米国人症例数である.これ をみると，アルコール硝子体の出現頻度は，日本例で9.2 \%，米国例で39.5\%で，これはアルコール硝子体を伴っ た急性フルコール性肝炎の頻度であある.更に,アルコ ール硝子体はないが, 恐らく急性〉ルコール性肝资の像 と思われる 2 群を含をと，日本例は $16.9 \%$ ，米国例は 65.1\%であった。これに対して，日本例では慢性肝炎の 症例が多く，46.1\%を占めるのに対し，米国例では8.4 \%に過きなかった. Table 2 は両国症例の肝硬変につい て険索したもので, 発生頻度, 肝硬変結節の大きさ, それに sublobular 大以上の比較的大きな壊死の存在の 頻度をみた．尚，肝硬変結節の大きさで, monolobular (Fig. 8) とは単小葉大及び亜小葉大の大きさの結節を 主とするすので，稀に肝小葉 $2 ， 3$ ヶ位の大きさの結 節を $1 ， 2$ ケ混在する症例む含めた. multilobular とは, 肝小葉 $4 ， 5$ ケ以上の大きさの結節を主とするるのであ るが, 2 3 小葉大の結節を混在する症例も含めた. し 
Table 1. Pathological diagnosis of 130 Japanese alcoholics and 238 American alcoholics ( $\bar{c}=$ with $\overline{\mathbf{s}}$ =without). Numerator represents numbers of Japanese cases and denominator represents those of American cases.

\begin{tabular}{l|c|c|c}
\hline \multicolumn{1}{c|}{ Groups } & $\left.\begin{array}{c}\mathbf{A} \\
(\overline{\mathbf{s}} \text { Cirr- } \\
\text { hosis }\end{array}\right)$ & $\begin{array}{c}\mathbf{B} \\
\mathbf{\mathbf { c }} \text { Cirr- } \\
\text { hosis }\end{array}$ & Total \\
\hline 1 Acut Alcoholic H & $5 / 62$ & $7 / 32$ & $12 / 94$ \\
2 Probable Acut Alcoholic & $7 / 47$ & $3 / 14$ & $10 / 61$ \\
H & $18 / 5$ & $24 / 6$ & $42 / 11$ \\
3 Chr Persistent H & $7 / 2$ & $11 / 7$ & $18 / 9$ \\
4 Chr Active H & $17 / 15$ & $5 / 8$ & $22 / 23$ \\
5 NSRH \& NSR* & $14 / 21$ & & $14 / 21$ \\
6 Fatty Liver & $8 / 14$ & & $8 / 14$ \\
7 Others & $4 / 5$ & & $4 / 5$ \\
8 NDAR** & $80 / 171$ & $50 / 67$ & 130cases/ \\
\hline \multicolumn{1}{c}{ Total } &
\end{tabular}

Number of Japanese Cases/Number of American Cases

* Nonspecific reactive hepatitis and nonspecific reaction

** No diagnostic abnormality recognized

Table 2. Incidence and histological characteristics of cirrhosis in 130 Japanese alcoholics and 238 American alcoholics

\begin{tabular}{c|c|c}
\hline & Japanese & American \\
\hline Incidence of Cirrhosis & $50 / 130(38.5 \%)$ & $67 / 238(28.2 \%)$ \\
$\begin{array}{c}\text { Size of Cirrhotic } \\
\text { Nodules }\end{array}$ & & \\
Monolobular & $25 / 50(50 \%)$ & $58 / 67(86.6 \%)$ \\
Multilobular & $25 / 50(50 \%)$ & $2 / 67(3.0 \%)$ \\
$?^{*}$ & $0 / 50$ & $7 / 67(10.4 \%)$ \\
Large Areas of & $6 / 50(4.6 \%)$ & $20 / 238(8.4 \%)$ \\
Necrosis \& Scars & & \\
\hline
\end{tabular}

* not clear due to extensive necrosis and scar

かしながら，米国人㱏例の 7 例にて，厷沉な submassive な壊死および激痕巣のために結節の大きさを決めること が出来なかった．日本例では multilobular な結節は50 $\%$, monolobular の結節も50\%であったが，米国例で は multilobular が $3 \%$ 過ぎず， monolobular の結節 は86.6\%にも及んた。。

尚, 写真 (Figs. 1 8) の症例は, 全て日本人例で, 米国人例は含まれていない。但し Fig. 3B のみは米国 症例のものである.

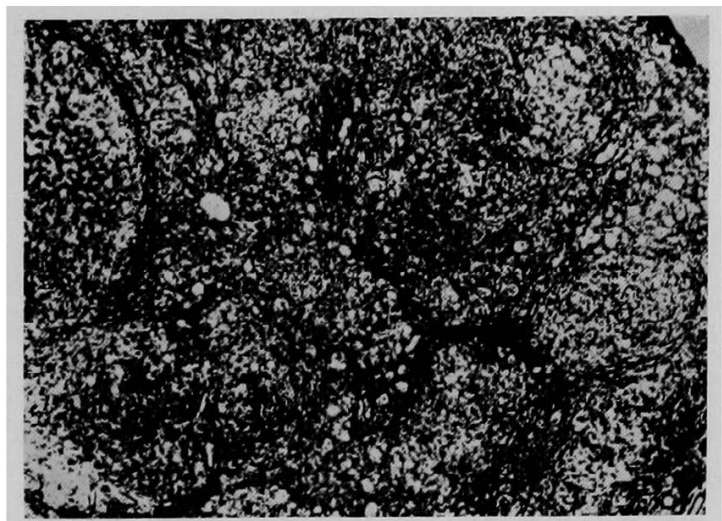

Fig. 8 Monolobular cirrhosis. The lobular architecture is distorted with small cirrhotic nodules of generally monolobular size. Diffuse perihepatocytic linear fibrosis and fat metamorphosis are characteristic. Acute alcoholic hepatitis is present in this case (Group 1. B) Azan-Mallory $\times 60$

\section{考察}

フルコール性肝障害は，大酒家にみられ，その领酒量 に関連する.最近，日本に於ける国民 1 人あたりの飲酒 量の著明な増加が指摘されているが，それでも米国に比 べればかなり少い”。しかしながら，本研究の対象にな った日本人症例中に哇，米国人症例飞，匹敵するような 大酒家む少くなかった. 本研究で、アアルコール消費量 については十分な検討を加えて拈らず，両国例とも，フ ルコール性肝障害の臨床診断のもとに，肝生検標本によ り形態学的検索がなされた症例である。

冒頭に取り上げるべき，両国間の大きな美は男女比で あろう. 欧米では，女性の大酒家は日本に比べかなり多 く、アルコール性肝障害をきたす例む非常に多い事がわ かる．欧米諸国では，女性（特に黒人女性）は素因的に 肝障害をきたしやすいといら点でアルコールに対して弱 く,5)，男性の $1 / 3$ 量でも肝障害をきたすす る. 日本で，女性症例が，非常に少いといら事は，フル コールに対して強いわけでなく，日本女性の领酒量が， 肝障害を起すほどには至っていないと云うのが，妥当と 思われる. しかし日本女性の 3 症例中， 1 例は肝硬变を 伴わない急性フルコール性肝炎（1 群A）であったが， この例ては毎日, 日本酒 3 合余しか飲んでおらず，かつ 比較的短期間の様で，日本女性む欧米之同様に肝障害の 見地からみてアルコールに弱いのかもしれない。

本邦に抽る、フルュール硝子体の 頻度は非常に低 い"，今回，我々9 $9.2 \%$ と云 3 頻度は非常に 高い数字 
である。これは、我々が皘極的に，他の病院からもアル コール性肝障害の患者を集め, 更に外の病院より紹介さ れた結果であり，この事から偏った数字で，日本を代表 する平㻌的数字とするには問題があろう．本研究での Cincinnati General Hospital と扰ける39.5\%と云う頻度 は，同様な症例を刘象にした米国の Birschback 等早の $32 \%$ と云う頻度よりも中や高く、デンマークにおける Christoffersen 等9 の10\%より明らかに高い，他にも，

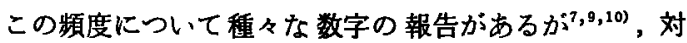
象の差異もあり安易に比較出来ない。尚、アルコール硝 子体は，1個でああれば1群に入れたが，一般に日本人 症例ではより数が少なかった.しかし，1群に属する日 本人症例の組織像は，米国人症例と，程度の差こそあ れ，その特徵は変らず，病変の主座は小葉中心部の肝細 胞の lytic necrosis と ballooning であり, 同部のアル コール硝子体であり，更に小葉中心部線維化，肝細胞索 に沿った線状の線維化，中心静脈壁の線維性肥厚もみら れた. 好中球浸潤は，日本人例でかなり軽度で特に，フ ルコール硝子体を有する肝細胞の周囲をとり囲む satellitosis の所見は殆んどみられなかった.この理由は，日 本人症例では，実際により軽度と云ら事である5が，さ らに肝生検の時期にもよると思われる. 全例についての 肝生検の時期飞ついては検索していないが，米国人の 1 群 $\mathrm{A}$ の症例では，入院後平均 8.5 病日に 肝生検を受けて いたが，日本人症例の 1 群 A, B ではかなりバラッキが あるが，平均20病日以上であり，一般に日本では，米国 に比へ，入院期が長く，肝生検も暑れて行われる傾向が あった．日本人症例飞もかなり强い小葉中心部肝細胞脱 落を伴った，小葉中心部線維化のある sclerosing hyaline necrosis の症例, 更にアルコール性肝硬変に特徽的な, regular monolobular cirrhosis るみれた. 亜小葉大以上 の大きな壊死, 又は症痕は, 日本人 1 群 $\mathrm{A}$ の症例には殆 んどみられず，この点からす，日本人症例の方がより軽 度であると云えよう．2群に括いても，阿国症例間に は，1群と同様な差をみた．逆に日本人大酒家に，最も 多く見られた病変は，慢性肝炎の像であり，米国人症例 では，この群の症例は少い。これら日本人慢性肝炎の 症例では, 领酒量はむしろ多く, 短日 1 升酒と云う症 例むかなりあった．組織学的に，これら日本人の慢性肝 炎には， 2 鍾類の type がるられる様である. 即ち，1 つは犬山分類にて，肝炎ウイルスに因ると想定されてい る普通の慢性肝炎であり，むら一つは，この通常の慢性 肝资にみられると同様な組織学的所見(門脈域のかなり
の慢性资症性細胞漫潤，線維化と症例によっては門脈域 周辺の限界板を不規則に切り崩す様な，肝細胞壊死）の 他に，既述した様な種々の諸変化，即ち中心静脈壁の線 維珄肥厚，小葉中心部線䑾化，perihepatocellular linear fibrosis, giant mitochondria，肝細胞の ballooning 招よ び脂肪化等，をみるものである．尚，日本の犬山分類 ${ }^{11}$ 飞従うと，慢性肝炎は主として肝焱ウイルスに因るもの と想定され，特にアルコールは除かれているため，慢性 肝炎の原因としてアルュールを認めている Acapulco 分 類にしたがった，両国大酒家にみる慢性肝资頻度の差は どこからくるのであろらか?日本では，米国よりる明ら かにB型ウイルス性肝资が多く，又B型肝炎ウイルスの carrier も多い，したがって，これら大酒家の慢性肝炎 に打ける，B型肝炎ウイルスの関与が問題になる。本研 究の対象となった症例，特に日本人症例では，B型肝炎 ウイルス持続感染に上る慢性肝资の可能性は，かなり否 定でると思らが，残念ながら血中 anti HBc の梌索， 更に組織レベルでの HBc 抗原の検索がなされていない ので完全には否定出来ない，更にB型肝炎をきっかけに 自己免疫機転により慢性肝炎が扰きた症例があれば，こ のウイルスの指標が既に陰性であっても，B型肝炎ウイ ルスの関与を否定出来ない：A型ウイルス肝炎る，以前 の日本には，かなり多かったようで ，本研究の対象 大酒家む，過去にこのウイルスに暴露されたと思われる か，このA型肝资の慢性化は，殆んどないと考えられて いる ${ }^{133}$. non A, non B ウイルス肝炎については, 現在 その指漂がなく，つかみよらがないが， B 型肝炎ウイル スの暮延している日本では，かなりその頻度が高いと推 測されこれによる慢性肝炎も否定出来ない，日本に特 有な日本酒，焼酎に関連して，その因を求める事も困難 であるが，以前に社会的問題となった防腐剂の添加等と の関連については確かでない，日本人のてルコールに対 する素因的な差に，その因を求める事む確かでない，最 後に問題になるのは，日本に抢けるフルコールによる慢 性肝资存在の可能性であろう。欧米では，アルコールす 慢性肝炎の原因の 1 つとして認められておりり，特に最 近む chronic active hepatitis との関連について報告か; ある ${ }^{14,15,16)}$. 発生機転は解明されていないが，急性フル コール性肝炎をきっかけとしての自己免度機転の他に， アルコール攝取量, 摄取様式, 個体差等により, 形態学 的に慢性肝炎の像をみるのかもしれない，即ち，比較 的少量，しかし長期の大酒により，完全に然えあがら ず，グズグズ長期にわたりくりかえされそして煄り続け 
る (smoldering) 肝細胞障害と，それに反応して門脈域 に慢性炎症細胞漫潤をみるのである。フルコール烣㾕 (addiction) の離脱のために，精神科に入院した大酒 家で, 肝障害の褴状の無い (no symptoms of organic liver disease) 12名 ( 5 ち5名は, 生化学的検查も異常 が無かった）に，肝生恰で組織学的に慢性肝炎の像をる た事は淿，この見解からみて興味深い。しかし，現在ま で，ラット，イヌ，七ト等を使用し，多数のアルニール 性肝障害の実匰がなされてきたが，慢性肝炎をつくり出 したといら報告はない。さらに肝生検の時期にる関連し て，形態学的愠性肝炎の像を見ることもあるようで， 大酒家で急性フルコール性肝炎の症状, 臨床所見等が扰 さまると，肝の組織像は，リンパ球，形質細胞等が增加 $\iota^{10)}$, chronic persistent hepatitis の像に類似する様で ある.いずれにせよ，肝资ウイルスの蒙延している日本 では，たとえ，既述したよらなアルコールによると思わ れる組織所見がこれらの慢性肝炎化付随してみられて む,これによって即ちこの慢性肝炎がアルコールに因る ときめつけるのは危険である.肝硬変像においても両国 間には大きな差がある。ここで注意したいのは，肝硬变 診断に対する肝針生検漂本の限界である。これに対して 我々は得られた生娭標本で， Sampling error による， multilobular な結節をもった肝硬変を見のがす事の無い 様，種々の組織学的所見（縦横，又は斜めに走る dense な線維索，肥大結節様に丸味を帯びた小葉周辺部，中心 静脈と門脈域の位置関係のゆがみ, 厚い肝細胞索, 肝小 葉内の異常な venule の存在等)に注意して検索を行 い,さらに釉局的には，肝の触知所見も参考にした．米 国例での我々の経釦は，今回の結果の様に，長期にわた る持続大酒家で入院前む大酒をのんでいた例（此較的年 龄は若い)を対象にする限り，肝硬変像は昔から指摘さ れている様に monolobular (又仕, micronodular) な結節 よりなる Gall の type $\mathbb{I}^{17)}$ (nutritional cirrhosis ${ }^{13)}$ ) であった. 一方, フルコール性肝硬変と云らべく特殊な 形の肝硬変はなく， multilobular (又は macronodular) の結節をむった Gall の type $\mathbb{I}^{17)}$ (posthepatitic ${ }^{18)}$ ) む みられると強く主張する者いいる.我々の滞米 4 年間の 限られた経験（しかし，症例検索は，過去にさかのぼっ て行ったが)では，確かに，その様な肝硬变も，大酒家 に少なからずみられたが，それは殆んど autopsy table でみられ，死亡前の何年か何十年か前にすでに大酒を止 め, 䠛床的に急性フルュール性肝炎の像を伴わない又 は，肝䑏に関して無症状の年老いた患者にみられた。特
にこの様な大酒家の multilobular の肝硬変は, Cincinnati General Hospital よりも，退役軍人の病院である Cincinnati Veteran's Hospital に多い様であり,これらの患 者が若い時に，海外に派遣されて，肝障害をひきおこす 他の agents (例, 肝炎ウイルス) に，接触する事す多か ったと思われ，単純にこの様な大酒家にみられた肝硬変 を全てフルコールによるものと云う事は危険であろう． もっとも僈性肝炎のところで既述したよらに，大酒によ ク, 何らかの機転により smoldering hepatitis が続け ば Gall の云う type III, posthepatitic cirrhosis この posthepatiticの hepatitis とは，肝における smoldering inflammation 即ち smoldering hepatitis の意味であり， 必ずしも, 即 viral hepatitis の意味では無い,しかし smoldering hepatitis の最もいい例は, B型肝炎ウイルス の carrier の肝でみられ，それにおそらく non A, non B 肝炎ウイルスの carrier にもみられるだろう)が扣き る事も考えられる.ささらに断酒後の肝硬变結節の肥大る ありらるであろう.日本人大酒家の症例は，全て米国例 と同様に，長年入院直前まで飲みつつけけていたが，米国 例と明らかに異る肝硬変像を示し, multilobular の結節 が多かった。この事実は，とりもな执さず アルコール 性肝硬変にも, multilobular の肝硬変も多いとする説の 証明ではなく，僈性旰炎で述べたと同様な種々の原因的 要素が考えられるだろう. 肝硬変に伴った sublobular 大 以上の壊死・激痕の頻度は, 日本 $(4.6 \%)$ に上り少な かった（米国8.4\%).

\section{結 論}

日本人大酒家 130 例と米国大酒家 238 例の肝病变を組織 的に比較検討し, 次の結果を得た.

1. 日本では，女性症例が非常に少ないこれは，日 本女性のアルュール撖取量が少いためであるら．

2. フルコール硝子体の出現頻度は，日本例で $9.2 \%$, 米国例で39.5\%，これは アルコール硝子体を伴った急 珄フルコール性肝炎の頻度でもある。フルコール硝子体 は無いが恐らく急性アルンール性肝资の像と思われる症

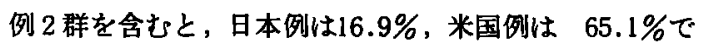
明らかに頻度は, 日本で少なかった.これはアルュール 摂取量が日本でより少ないためと思われる。ささらに組織 像の重症度も，日本例でより軽症であったが，本質的な 組織像は变らなかった。

3. 逆深本人には，慢性肝资の症例が多く（日本例 $46.1 \%$ ，米国(例 $8.4 \%$ ）ささらに肝硬変も multilobular の 結節をもった症例がより多かった（日本例50\%，米国例 
$3 \%)$ ，これは，飲酒量，飲酒様式，食餉，人種的素因の 差か，又は 日本により瞢延していると思われるB型和 よび non A, non B 肝炎ウイルス等の関与によるものか 不明である。しかし，これらの症例を即アルコールによ る慢性肝资とよふ事は，特に日本の様な肝炎ウイルスの 瞢延国においては危険であり，今後の検索が待たれると ころである。

本論文の要旨は，第14回日本肝㔉学会総会にて発表し た。

謝辞：稿を格えるにあたり，米国 University of Cincinnati Medical Center 病理 Dr. Antonio Chedid, Dr. Edward A. Gall $と$ Director $の$ Dr. Roger D. Smith の 御指導と御協力に感啸致します。

\section{文献}

1) Takeuchi, J. \& Takada, A.: Alcohol and its hepatotoxic effect. In alcoholic liver pathology, ed. Khanna, J.M. et al. Alcoholism and drug research foundation of Ontario, Toronto, 1975, p. 199.

2）伊藤 進他：アルコール性肝炎纪関する臨床病 理学的知見. 肝臓, $14: 717,1972$.

3) Leevy, C.M. \& Tygstrup, N.: Standardization of nomenclature, diagnostic criteria and diagnostic methodology for diseases of the liver and biliary tract. S. Karger, Basel, 1976, p. 8.

4) Lischner, M.W. et al.: Natural history of alcoholic hepatitis, 1. the acute disease. Digest Dis., 16: 481, 1971.

5) Kramer, K. et al.: The increasing mortality attributed to cirrhosis and fatty liver in Baltimore (1957-1966). Ann Intern. Med., 69: 273, 1968.

6) Wilkinson, P. et al.: Epidemiology of alcoholic cirrhosis. Aust. Ann Med., 18: 222, 1969.

7）土屋雅春，松崎松平：フルコールと肝障害 フ ルコール中毒, 1 版, 加藤伸勝他, 医学書院, 東
京, 1973. p. 133.

8) Birschback, H.R. et al.: Alcoholic steatonecrosis. II prospective study of prevalence of Mallory bodies in biopsy specimens and comparison of severity of hepatic disease in patients with and without this histological feature. Gastroenterol, 66: 1195, 1974.

9) Christoffersen, P. \& Nielsen, K.: The frequency of Mallory bodies in liver biopsies from chronic alcoholics. Acta Pathol. Microbiol. Scand., (Section A) 79: 274, 1971.

10) Galambos, J.T.: Natural history of alcoholic hepatitis: III Histological changes. Gastroenterology, 63: 1026-1035, 1972.

11）犬山シンポジムム記録刊行会：慢性肝炎一その 後. 第 6 回犬山シンポシ்ム, 中外医学社, 東 京, 1975 .

12）森次保雄他：日本に批けるA 型肝炎の予棤的調 查. 肝臟, $19: 237,1978$.

13）鉿木 宏, 三田村圭二：A型肝炎. 内科，39： $371,1977$.

14) Galambos, J.T.: Chronic active hepatitis and ethanol-A from of drug hepatitis?. Gastroenterology, 68: 1075, 1975.

15) Goldberg, S.J. et al.: "Nonalcoholic" chronic hepatitis in the alcoholic, Gastroenterology, 72: 598, 1977.

16) Bruguera, M. et al.: Asymptomatic liver disease in alcoholics. Arch Pathol. Lab. Med., 101 : 644, 1977.

17) Gall, E.A.: Posthepatitic cirrhosis, fact and fancy. In controversy in internal medicine, ed. Ingelfinger, F.J., WB Saunders, Philadelphia, London, 1966, p. 244.

18) Gall, E.A.: Posthepatitic, postnecrotic, and nutritional cirrhosis, A pathologic analysis. Am. J. Pathol., 36: 241, 1960. 


\title{
Pathological Study on Alcoholic Liver Diseases in High and \\ Low Incidence Countries: Comparison between Cincinnati,
}

\author{
U.S.A. and Tokyo, Japan \\ Tsutomu Karasawa, Toshio Shikata*, Tomoko Kushida, \\ Haruo KaNEDA and Hitoshi OHKUBo**
}

To deliniate histopathological features of liver diseases seen in Japanese alcoholics, 130 Japanese alcoholic patients were studied in comparison with 238 American alcoholic cases.

In Japan female alcoholic patients were extremely rare. Although all aspects of alcoholic liver disease did exist in Japan, typical cases of acute alcoholic hepatitis with alcoholic hyalins were remarkably smaller in number. In contrast to this, 46 percent of Japanese alcoholic patients had chronic hepatitis, and the incidence of multilobular cirrhosis was much greater in Japan with higher prevalence of hepatitis viruses.

* The First Department of Pathology, Nihon University School of Medicine (Tokyo)

** The Third Department of Internal Medicine, Nihon University School of Medicine 